\title{
Practice and Thinking of Bilingual Teaching of International Commercial Law
}

\author{
Xiaopeng Zhang \\ Chengdu Neusoft University, Chengdu, Sichuan, 611844
}

Keywords: international commercial law; bilingual teaching; practice thinking

\begin{abstract}
The international nature of international commercial law has determined that it will inevitably involve a large number of foreign languages in terms of teaching content, methods, etc. Therefore, if one single use of the entire Chinese language is to be taught, it is bound to be unfavorable to students' understanding and mastery of knowledge, and it is not conducive to the students learning knowledge being used directly in practice. This paper tries to proceed from the concept of bilingual teaching, analyzes and thinks about bilingual teaching in international commercial law, and finally gives some suggestions.
\end{abstract}

\section{Introduction}

As one of the 12 measures proposed by the Ministry of Education to strengthen undergraduate teaching, universities and colleges are required to open 5\%-10\% of bilingual courses within three years, and at the same time improve the level of teachers and introduce original textbooks. In order to meet this requirement, each school law school has also set up bilingual courses for students majoring in law, and the characteristics of international commercial law determine that this course is often the first choice for opening. In the following, the bilingual teaching method of international commercial law will be analyzed and discussed starting from the concept of bilingual teaching.

\section{The Importance and Difficulties of Bilingual Teaching in International Commercial Law}

First, international business law is a course of comparative law. The legal norms and related cases of other countries, as well as international treaties and international conventions, are the focus of teaching content. English is the original text language of most international treaties and international conventions. The analysis of the original English text will not only improve students' understanding and use of legal English vocabulary, but also open up new ways for students to read the actual meaning of the text. Secondly, many students have plans to go abroad for further studies, and advanced teaching concepts and scientific curriculum settings in foreign education will test the adaptability of Chinese students. Therefore, bilingual education is more convenient for the convergence of different knowledge points related to different courses, and is also more conducive to the convergence of the domestic learning phase and the foreign learning phase. Furthermore, the practical work of future graduates of international trade and international business will involve foreign-related contracts in most cases. Therefore, from a practical point of view, international commercial law courses should be bilingual.

However, both teachers and students face many difficulties in the development of bilingual teaching. The student's English level directly determines the ability to receive information and the total amount of knowledge received. The students' English is not balanced, making it difficult to grasp bilingual teaching in both English and Chinese. In the classroom, students cannot fully understand the teacher's English explanation. They can't use English as a tool to read. They can't freely use English writing skills to complete their homework after class. These situations make it difficult for the teacher to organize and teach the class. In addition, the characteristics of the ICC curriculum itself are also one of the reasons why students feel that the course is difficult. The content of international commercial law is numerous and the knowledge points are intertwined. It needs to involve both the domestic law and the international law. The huge amount of information often makes students daunting. In addition, professional terminology is also a difficult point. Some 
common vocabulary commonly used in daily communication has a completely different meaning in international commercial law. For example, the word "consideration" is an English word. Students all know that this is a consideration, but they are read in the textbook of international commercial law. The reason why it can't be understood is because the word refers to "consideration", a term in contract law. Therefore, how to set reasonable teaching goals and how to use various teaching methods and resources to overcome these difficulties become the key to bilingual education in international commercial law.

\section{Objectives and Setting of Teaching Contents of Bilingual Teaching}

The author thinks that starting from the purpose of the teaching of international commercial law, bilingual education should be positioned to use English to acquire professional knowledge, and at the same time to develop students' ability to use English to solve problems in the practice of international commercial legal affairs. Specifically speaking, teachers should place students' understanding and acceptance of professional curriculum knowledge points at the top of the teaching goal. Due to the limitations of English communication skills, students are difficult to understand in course teaching. They should not be forced to explain in English and apply Chinese as an appropriate explanation. The intervention of the mother tongue can be increased or decreased according to the level of the students and the degree of difficulty in teaching the content. The goal is to realize the transition from bilingual teaching to teaching in English so as to truly achieve the purpose of teaching international commercial law. Secondly, in the bilingual teaching of international business law, teachers should create as much as possible an English-speaking environment for students, including the preparation of courseware and the use of English in lectures. This will allow students to immerse themselves in the English language environment of international business law. Inspire them to freely discuss, ask questions in English and improve their ability to use English.

The total number of international business law courses is 54 hours. If you cover everything and focus on introducing all the content to students, students will have a hard time grasping what they are talking about. The learning effect will be unsatisfactory. Therefore, to achieve the best teaching results in a very limited time, how to choose teaching content is particularly important. For international trade and international business students, the most closely related to future practice should be the contents of the contract law and the commercial organization law, so it should be emphasized. WTO and other international economic and trade organizations and intellectual property laws should focus on introduction and understanding.

\section{Selection of Teaching Materials and Development of Teaching Resources}

The choice of teaching materials is very important in bilingual teaching. At present, in the teaching practice, most of the following four teaching materials will be selected: the original English textbooks, the English-Chinese version of the textbooks, the school's own textbooks and the original adapted textbooks. The author believes that compared with other types of textbooks, English original textbooks can directly and accurately reflect the more advanced teaching concepts and more systematic and comprehensive arrangements for professional education in foreign educational institutions. Therefore, the English original textbooks should be bilingual practice. The first choice. Faced with many textbook versions abroad, how do we select teaching materials suitable for Chinese students? Many domestic scholars have put forward relevant suggestions. The author also agrees that the following factors should be fully considered when selecting teaching materials: First, the content system should be compatible with international trade and The international business professional teaching program adapts, taking into account the connection with the teaching content of other related courses; Second, the language expression can adapt to the students' reading habits as much as possible. The understanding of the legal language itself is difficult, so it is not appropriate to choose language lengthy teaching materials.

In addition to having good teaching materials as a basis for classroom teaching and reading after 
class, the development of diversified teaching resources not only plays a complementary role in the teaching materials, but also helps students to expand their knowledge and activate the classroom atmosphere. (1) Charts summarizing various types of summaries. As mentioned above, the knowledge structure of international commercial law is complex and there are often criss-crossing knowledge points. Proper use of inductive graphs can help students better sort out their knowledge and gradually construct a three-dimensional knowledge network. For example, when explaining the risk transfer problem of various trading terms, a horizontal comparison can be made by using the chart to indicate the risk transfer points of each term at the same time. (2) Extracurricular reading materials. Most of the textbooks are the most basic and basic content of this subject, and they can not fully meet the needs of teaching. Teachers, as developers of teaching resources, should select appropriate reading materials to help students achieve self-directed learning. For example, according to the content of teaching, teachers can choose some British and American courts' judgments to read by students. Students can effectively combine theoretical knowledge and practical operations through free discussion and teacher's explanation. On the one hand, they can fully understand abstract legal provisions and The meaning of legal theory, on the other hand, adds a lively atmosphere for boring classroom learning. (3) Video data. The proper introduction of English video materials in classroom teaching can not only enhance the interest of classroom teaching, improve students' participation in class, but also enable students to master relevant legal language culture and legal knowledge in the real context. For example, in the introduction of the WTO, students were given an introduction clip recorded by the WTO specifically for the students. This fragment was based on what the two middle school students visited during the visit to the WTO headquarters. The structure of the WTO and various departmental functions were clearly and clearly explained. To explain, let the students have the immersive feeling, the learning effect is naturally much better than teachers according to the script.

\section{Application of Case Teaching Method}

Case law is the most important legal source in Anglo-American legal system countries. Case teaching method is the main teaching method of legal education in these countries. Similarly, case analysis in the international commercial law curriculum is a necessary means to study the legal systems of these countries. As we all know, the most effective means for students to master their knowledge is to highly integrate theoretical knowledge and practice. In legal learning, various cases are the best materials for teachers and the best platform for students to participate in practice during their studies. Through the discussion and explanation of the case, the students and teachers will integrate all the knowledge points and infiltrate the case study to apply them to achieve the unity of learning and practice.

The form of case teaching method is diverse. It can be a classroom case assessment, or it can be an extracurricular practice or case audition. However, due to the limited class time, the main form of classroom case analysis should be adopted. Teachers should pay attention to several points when selecting cases. First, the case was chosen to match the teaching content. Therefore, we should choose a representative case that suits the teaching process, such as historically determining a legal principle, a far-reaching classic case, or a typical case currently occurring. Second, the degree of difficulty of the case should be close to the actual level of the student. Cases that are too difficult will make students feel that they cannot start. They can only passively wait for the analysis of teachers in the classroom, which greatly undermines students' autonomy in learning. Excessive cases may not require in-depth thinking and analysis to reach conclusions, but also reduce student participation in the case. Third, new cases should be selected as far as possible. If you always choose an outdated case, students will feel that the course is out of touch with reality and the motivation for learning is reduced.

\section{Conclusion}

The international commercial law teaching of international trade and international business 
should be based on the pre-established bilingual education goals, combined with the actual conditions of the students, make full use of various teaching resources, and use case teaching methods to create an enlightening and practical approach for students. Sexuality and fun as a bilingual learning environment.

\section{References}

[1] Chen Jingying. On International Commercial Law Teaching under Different Audiences_-Teaching Students Majoring in Law and Illegal Studies as Subjects [J]. American-Chinese Law Review, 2007, (2).

[2] Bao Lu. On the Application of Case Teaching Method in Law Teaching in China [J]. Journal of Foreign Trade University, 2003, (4).

[3] Shen Muzhu. Bilingual Teaching in International Trade Law [J]. Journal of Southwest University for Nationalities (Humanities and Social Sciences), 2004, (3).

[4] Yang Fuying. Analysis of the Dilemmas and Countermeasures of Bilingual Teaching in International Business Law [J]. Journal of Yangzhou Vocational University, 2006, (4)

[5] Zhang Qian. Argumentation and Reflection on Establishing Bilingual Teaching-oriented University [J]. Education Science, 2001, (4): 60. 